\title{
Milk Production of Holstein Friesian Dairy Cows in Various Lactation Periods (Case Study at Capita Farm, Semarang, Central Java)
}

\author{
Rudy Hartanto ${ }^{* *}$, Alvian Adhi Pamungkas ${ }^{b}$, Edi Prayitnoc, Dian Wahyu Harjantid \\ $a, b, c, d$ Laboratory of Beef and Dairy Sciences, Department of Animal Science, Faculty of Animal and Agricultural Sciences, Diponegoro \\ University, Semarang City, Central Java 50275 \\ email:*rudyharta@gmail.com; rudyhartanto@lecturer.undip.ac.id
}

A R T I C L E I N F O

Article history:

Received 29 Juli 2020

Revised 20 Agust 2020

Accepted 09 Sept 2020

Available online 12 Okt 2020

Keywords:

Lactation Period

Milk Production

Holstein Friesian

Capita Farm

IEEE style in citing this article: R.Hartanto, A.A. Pamungkas, E. Prayitno and D.W. Harjanti, "Milk Production of Holstein Friesian Dairy Cows in Various Lactation Periods (Case Study at Capita Farm, Semarang, Central Java)" Jurnal Ternak vol. 11, no. 2, pp. $44-49,2020$.
A B S T R A C T

The purpose of this research was to determine and to assess the milk production of Holstein Friesian cows in Capita Farm based on its lactation period. The research was conducted on $29^{\text {th }}$ September $-28^{\text {th }}$ October 2019 . The materials used in the study were $59 \mathrm{FH}$ dairy cows in the lactation period of 1-6 and lactation months of 1-10. The body weight was $497.71 \pm 44.73 \mathrm{~kg}$ and the milk production was $14.43 \pm 4.43$ liters / day / head. The study was conducted by observation. The parameters observed were the lactation period and daily milk production. Afterward, the daily milk production was converted into milk production in one lactation period. The difference in milk production of one lactation period between the lactation periods was determined by the independent sample $t$ test at level of $5 \%$. The results of this research showed that the peak production in the $4^{\text {th }}$ lactation period was 4458.26 liter/lactation, while the $1^{\text {st }}, 2^{\text {nd }}, 3^{\text {th }}, 5^{\text {th }}, 6^{\text {th }}$ lactation periods were 3976.85; 4100.01; 4143.85; 3850.27; 2938.56 liter/lactation, respectively. The $6^{\text {th }}$ lactation period was significantly lower than the others with production capability of $65.91 \%$ of the mature equivalent (ME). It was concluded that the Holstein Friesian dairy cows in Capita Farm has the highest production in the $4^{\text {th }}$ lactation period, but there is a real difference in production when it enters the $6^{\text {th }}$ period.

\section{Introduction}

In Indonesia, small farms still dominate dairy farming and generally those raising Holstein Friesian cows. This is because the amount of the milk production of Holstein Friesian cows is higher than other cows and has been able to adapt to the tropical climate in Indonesia [1, 2, 3]. Holstein Friesian cows on small farms in Central Java, on average, were able to produce 10-12 liters of milk / day $[4,5]$. This milk production is influenced by external factors and internal factors. External factors include climate and rearing management including feed management and housing management. Internal factors include breeds, age of cows, lactation period and month of lactation of dairy cows [6, $7,8]$.

The peak production of milk for dairy cows per lactation period generally occurs in lactation months 1-2 [9], with the ideal lactation period of about 10 months or 305 days [3, 10, 11]. Milk production capacity differs between lactation periods [12]. Meanwhile, the highest milk production during his life occurs when the body was fully grown or when he reached 6-7 years of age and the lactation period was 4 , and was rejected when it was 11-12 years old [6,12]. Nonetheless, if the location of the farms is different, it is likely that the length of the lactation period and the milk production per lactation period will not be exactly the same, even though the dairy cows are the same breeds. This 
depends on the genetics of the cow and the management of the rearing. The Holstein Friesian cows that are well maintained and fulfilled nutrient needs will have a long lactation period or a longer productive life with relatively good milk production [13, 14]. In addition, the reproductive performance of dairy cows is also influenced by the lactation period [8].

Capita Farm is a modern dairy farm located in Semarang Regency, Central Java. To maintain company performance, data display of milk production to determine when is the best lactation period was needed to evaluate productivity and rearing management in order to optimize revenue and the continuity of company production. Therefore, this research was conducted with the aim of determining and assessing the milk production of Holstein Friesian cows in Capita Farm based on their lactation period.

\section{Materials and Methods}

\subsection{Materials}

This research was conducted on $2^{\text {th }}$ September $-28^{\text {th }}$ October 2019 at Capita Farm, Semarang Regency, and Central Java. The cows used were 59 Holstein Friesian cows in the lactation period 1-6 and lactation months 1-10. At the time of observation, this Holstein Friesian cows had a body weight of $497.71 \pm 44.73 \mathrm{~kg}$ and daily milk production of $14.43 \pm 4.43$ liters / day / head.

\subsection{Methods}

This research was conducted by observation, without giving any treatment to livestock. The parameters observed were the period of lactation, month of lactation and milk production on certain days at the time of the study. Afterward, daily milk production was converted to milk production in one lactation period with guidance from Murti [6] and Utomo [15] using the following formula:

Milk production in one lactation period (liter/head) $=$

$\frac{100 \%}{\% \text { Lactation Month }} \times 30 \times$ daily milk production

$\%$ lactation month: $1^{\text {st }}$ month $(13 \%), 2^{\text {nd }}$ month $(13 \%), 3^{\text {th }}$ month $(12 \%), 4^{\text {th }}$ month $(11 \%), 5^{\text {th }}$ month $(11 \%), 6^{\text {th }}$ month $(10 \%), 7^{\text {th }}$ month $(9 \%), 8^{\text {th }}$ month $(8 \%), 9^{\text {th }}$ month $(7 \%), 10^{\text {th }}$ month $(6 \%)$.

Percentage of milk production in a specific lactation period $(\% \mathrm{ME})=$

$\frac{\text { Milk production in a spesific lactation period }}{\text { Milk production in the peak lactation period }} \times 100 \%$

\subsection{Statistical Analysis}

The difference in milk production in one lactation period between lactation periods was determined by the independent sample $t$ test at the $5 \%$ significance level. To increase accuracy, IBM SPSS 25 was used in the calculation process [16, 17].

Table 1. Average Milk Production in Each Lactation Period at Various Lactation Periods

\begin{tabular}{ccccccc}
\hline Variable & P1 & P2 & P3 & P4 & P5 & P6 \\
\hline $\mathrm{n}$ & 14 & 12 & 9 & 10 & 7 & 7 \\
AMP (liters/lactation) $^{*}$ & $3976,85^{\mathrm{a}}$ & $4100,01^{\mathrm{a}}$ & $4143,85^{\mathrm{a}}$ & $4458,26^{\mathrm{a}}$ & $3850,27^{\mathrm{a}}$ & $2938,56^{\mathrm{b}}$ \\
$\begin{array}{c}\text { Percentage of Production } \\
\text { (\% ME) }\end{array}$ & 89,20 & 91,97 & 92,95 & 100 & 86,36 & 65,91 \\
\hline
\end{tabular}

* $\mathrm{AMP}=$ average milk production in one lactation period, $\mathrm{P}=$ lactation period, $\mathrm{n}=$ number of cows $\mathrm{a}, \mathrm{b}$ A significant difference is indicated by different superscripts on the same line $(\mathrm{P}<0,05)$ 


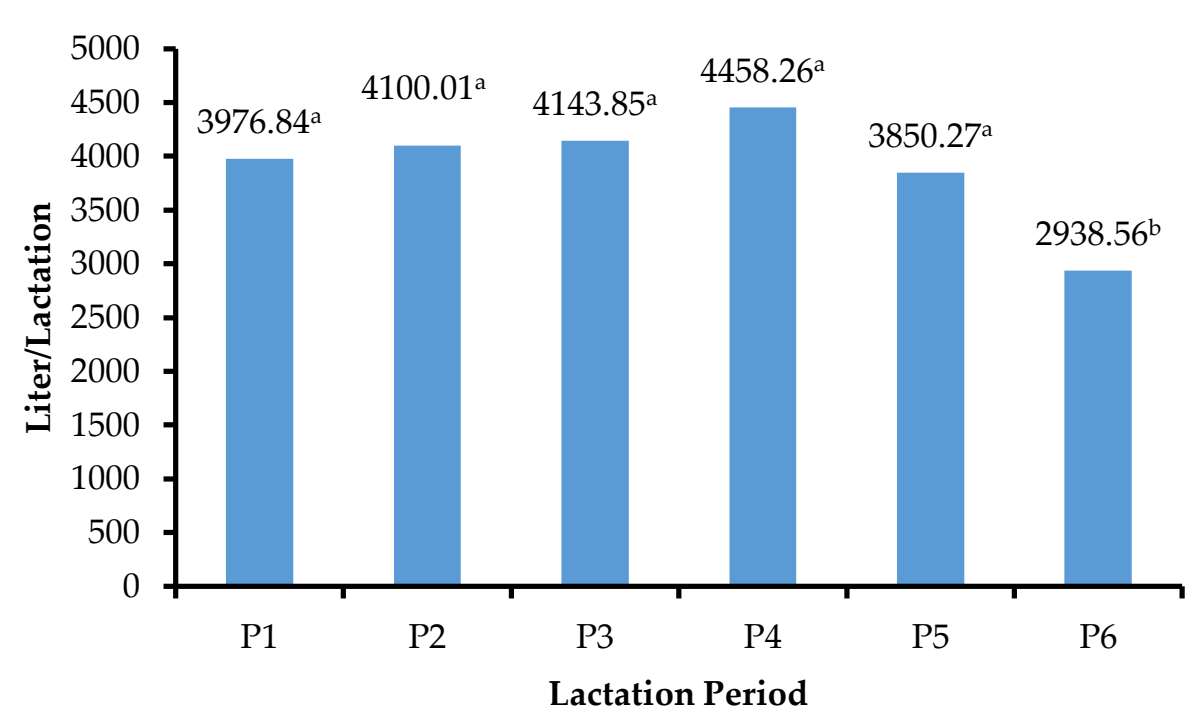

Figure 1. Bar Chart of Milk Production in Each Lactation Period at Different Lactation Periods

\section{Results and Discussion}

The results of the calculation of the average milk production at each lactation period at various lactation periods were listed in Table 1 and Figure 1. The results of different tests between periods in the milk production of one lactation period showed a significant difference $(\mathrm{P}<0.05)$ in the $6^{\text {th }}$ lactation period with the $1^{\text {st }}, 2^{\text {nd }}, 3^{\text {th }}, 4^{\text {th }}, 5^{\text {th }}$ lactation period which can be seen in Table 1 . Based on the results of the average milk production at each lactation period at various lactation periods, a bar chart was obtained as shown in Figure 1. This description of milk production explained that from the first lactation period it had increased to the peak of milk production in the $4^{\text {th }}$ lactation period, and then decreased until the $6^{\text {th }}$ period. Starting from the $1^{\text {st }}$ lactation period to the $4^{\text {th }}$ lactation period there was an increase, after that there was a decrease in the $5^{\text {th }}$ lactation period but from the $1^{\text {st }}$ period to $5^{\text {th }}$ it was not significantly different, and when entering the $6^{\text {th }}$ lactation period the decrease in milk production was significant. These results indicated that this difference was due to the lowest milk production in the $6^{\text {th }}$ lactation period compared to the other lactation periods due to the aging of the cows, so that the body's metabolic function was decreased. Yoon et al. [18] stated that milk production is closely related to the lactation period. According to the reports from Sangbara[19], Utomo[15] and Murti [6], that the age of dairy cows reached peak milk production at the age of 6-7 years and in the $4^{\text {thlactation }}$ period, then milk production decreased because the cows were getting old. Martinet et al. [20] and Makin [12] also stated that milk production after reaching peak production continued to decrease because the function of secretory cells decreased due to more damage than repair. Capuco et al. [20] reported that during lactation, only $0.3 \%$ of mammary cells proliferated in a 24-hour period, and this increased even more during dry periods. However, after passing through the peak period $\left(4^{\text {th }}\right.$ lactation period), the rate repair of secretory cells during the dry period also remained lower than the rate of damage, therefore, it caused the total milk production in the next lactation period decreased.

In our study, the increase in milk production in one lactation period ( $1^{\text {st }}$ up to $4^{\text {th }}$ lactation periods) was due to a process of enlargement and repair of secretory cells in udder to the peak of lactation in the $4^{\text {th }}$ period, then began to decline ( $5^{\text {th }}$ and $6^{\text {th }}$ lactation periods) due to cells secretory damage more than repair as a result of continuous milk synthesis. This is align with Makin [12] which stated that milk production will continue to increase until the peak of the $4^{\text {th }}$ lactation period because cows are still improving the mechanism of the hormones estrogen and progesterone in the body which causes enlargement and repair of secretory cells in the udder, then the next lactation decreases because hormone work in the body decreases due to the age of the cow getting old. In addition, during the $4^{\text {th }}$ lactation period, cows have reached maturity and do not grow anymore so that they have optimal body weight, body size and udder volume. Damayanti et al. [22] stated that udder volume was closely related to milk production. The lactation period can be influenced by factors of 
good rearing and cool climatic conditions around the environment. Makin and Suharwanto [23] stated that in general the length of the lactation period was influenced by the climate and environmental conditions, where Holstein Friesian dairy cows in cool areas had a longer lactation period than Holstein Friesian dairy cows in hot areas.

The percentage of milk production based on the peak of production (4th lactation period) in Table 1 showed that during the $6^{\text {th }}$ lactation period, milk production was lower in value than the others. Nonetheless, this percentage was slightly different from Murti [6] statement that the first lactation period reflects $80 \%$ of the peak production (mature equivalent $(\mathrm{ME})$ ), while the $2^{\text {nd }}, 3^{\text {rd }}, 4^{\text {th }}$, $5^{\text {th }}, 6^{\text {th }}$ lactation period were $90,95,100,90$ and $85 \%$ ME production. This happened because apart from the lactation period there were other internal factors such as breeds and individual cows, although one breeds if the individuals were different, their genetic abilities are not exactly the same [6, 24]. In addition, the percentage of milk production was also influenced by the age at birth [7], although the lactation period was the same, if the age at birth was different, the percentage of ME production can also be different. External factors such as feed management and livestock health also affected the percentage of milk production in a certain period seen from milk production during the peak period (4 $4^{\text {th }}$ lactation period) [6]. The higher the percentage of peak production reflected that the milk production in that period was also getting bigger and closer to the amount of milk production at the peak of production. The recorded data of 59 lactating cows in this study showed that the cows had their $1^{\text {st }}$ birth when they were $2.5-3$ years old, their $4^{\text {th }}$ birth at the age of 6-7 years and their $6^{\text {th }}$ birth when they were 8-9 years old. The phenomenon of the highest milk production in the $4^{\text {th }}$ lactation period was in line with the quality of milk reported by Sudiana et al. [25] that stated, the best milk quality also occurred in the $4^{\text {th }}$ lactation period although it was not statistically significant. Meanwhile, Wulandari et al. [26] stated that the quality of milk based on density and total solid milk did not differ between the $1^{\text {st }}$ and $2^{\text {nd }}$ lactation period.

Milk production in $6^{\text {th }}$ lactation period which was significantly lower than previous periods indicated a decline in the ability of dairy cows to produce milk due to secretory cell damage which was faster than repair. Thus, it was assumed that if the dairy cows were reared for $\geq 7$ lactation periods, the company was considered inefficient, meaning that the production costs were higher than the value of the milk products produced. This result was in line with the Capita Farm policy, which will reject lactation cows after passing the $5^{\text {th }}$ lactation period, except for cows with very good performance, they kept until the $6^{\text {th }}$ lactation period. Based on Table 1, it can be seen that the lactation cows in Capita Farm during $6^{\text {th }}$ lactation period were still able to produce 2938.56 liters of milk / lactation or 9.6 liters / day (with a lactation period of 305 days). The policy of rejecting lactation cows was indeed different from people's farms, where the ownership of cows and their capital was much smaller than that of large companies. According to Amam and Harsita [27], lactation cows in smallholder farms were usually rejected when daily milk production was below 3 liters / day.

\section{Conclusions}

Based on the results of the research at Capita Farm, it was concluded that the Holstein Friesian dairy cows showed the highest production in the $4^{\text {th }}$ lactation period, but there was a significant difference in production when entering the $6^{\text {th }}$ period.

\section{Acknowledgment}

We would like to thank Capita Farm for allowing this research in its location, and thanks also to the editors and reviewers for their valuable suggestions.

\section{References}

[1]D. Al Kurnia and Q. Cita K.N.S., "Effectiveness of black grape seed and skin dipping on the milk quality of tropical dairy cows", Jurnal Ternak, vol. 9, no. 1, pp. 1-7, 2018.

[2] M.A. Kartiko, P. Sambodho and D.W. Harjanti, “Physiological responses of lactating cows by the effect of environmental modified barn", Agromedia, vol. 37, no. 2, pp. 76-82, 2019. 
[3] D.S. Tasripin, R.F. Christi and D.D. Biyantoro, "Milk production and lactation period for Holstein Friesian dairy cows at PT Ultra (UPBS), South Bandung", Composite, vol. 2, no. 1, pp. 25-29, 2020.

[4] DistanpanganMagelang Regency Government, "Dairy Cattle Field School, Sumberejo Village, Ngablak: Efforts to Increase Magelang Milk Production", https://distanpangan.magelangkab.go.id/home/detail/sekolah-lapang-ternak-sapi-perah-di-desasumberrejo-ngablak-upaya-peningkatan-produksi-susu-magelang/121, Accessed $20^{\text {th }}$ August 2020.

[5] D.W.Solechah, D. W. Harjanti and R. Hartanto, "Relationship between udder morphology, milk production and milk components of Holstein Friesian cows", JurnalAgripet, vol. 19, no. 2, pp. 91-98, 2019.

[6] T.W. Murti, "Management Science and Industry in Dairy Cattle", Pustaka Reka Cipta, Bandung, 2014.

[7] S.A. Santosa, A.T.A. Sudewo and A. Susanto, "Creating milk production correction factors of dairy cattle", Jurnal Agripet, vol. 14, no. 1, pp. 1-5, 2014.

[8] A. Mahmud, W. Busono and P. Surjowardojo, "Reproductive performance Holstein Friesian cattle in various lactation period", Jurnal Ilmiah Peternakan Terpadu, vol. 6, no.1,pp. 89-92, 2018.

[9] K. Nugroho, A. Anang and H. Indrijani, "The comparison of milk production curve model on $1^{\text {st }}$ and $2^{\text {nd }}$ lactation Holstein Friesian based on the daily record", Jurnal Ilmu Ternak, vol. 15, no. 1, pp. 30-35, 2015.

[10] DeLaval, "Cow Comfort: Milking", http://www.milkproduction.com/Library/Scientificarticles/Housing/Cow-comfort-15/. Accessed 20 th August 2020.

[11] R. Dyah, "Lactation", BBPTUHPT Baturraden, http://bbptusapiperah.ditjenpkh.pertanian.go.id/?p=4631. Accessed 20 $0^{\text {th }}$ August 2020.

[12] M. Makin, "Dairy Farm Management", first edition, Graha Ilmu, Yogyakarta, 2011.

[13] S. Rusdiana and W. K. Sejati, "Measures for dairy cattle agribusiness development and milk production enhancement through dairy co-operatives empowerment", Forum Penelitian Agro Ekonomi, vol. 27, no. 1, pp. 43-51, 2009.

[14] J. Moran and P. Chamberlain, "Blue Prints for Tropical Dairy Farming: Increasing Domestic Milk Production in developing Countries", CSIRO Publishing, Clayton South, 2017.

[15] O.T. Utomo, "Proportion of Holstein Friesian Cow Milk Production During Lactation at PT Rejosari Bumi - Tapos Unit, Cileungsi, Ciawi, Bogor, West Java", Faculty of Animal Science, Gadjah Mada University, Yogyakarta (Thesis), 2013.

[16] IBM Corp, "IBM SPSS Statistics for Windows, Version 25.0.", Armonk, NY: IBM Corp, Released 2017.

[17] C. Gunawan, "Proficient in Mastering SPSS: Easy Data Processing with IBM SPSS Statistic 25", first edition,Deepublish, Yogyakarta, 2018.

[18] J.T. Yoon, J.H. Lee, C.K. Kim, Y.C. Chung and C.H. Kim, “Effects of milk production, season, parity and lactation period on variations of milk urea nitrogen concentration and milk components of Holstein dairy cows", Asian-Australasian Journal of Animal Sciences, vol. 17, no. 4, pp. 479-484, 2004.

[19] Y. Sangbara, "The Effect of Lactation Period on Milk Production in Holland Friesian Dairy Cows in Enrekang Regency", Faculty of Animal Science, Hasanuddin University, Makassar (Thesis), 2011.

[20] J. Martinet, L.M. Houdebine and H.H. Head, "Biology of Lactation", Quae, French, 1999.

[21] A.V. Capuco, S.E. Ellis, S.A. Hale, E. Long, R.A. Erdman, X. Zhao and M.J. Paape, "Lactation persistency: insights from mammary cell proliferation studies". Journal of Animal Science, vol.81, no. 15,pp. 18-31, 2003.

[22] R.Damayanti, R. Hartanto and P. Sambodho, " Correlation of udder volume and nipple size with milk production of Holstein Friesian dairy cows at PT. Naksatra Kejora, Temanggung Regency", Jurnal Sain Peternakan Indonesia, vol. 15, no. 1, pp. 75-83, 2020.

[23] M. Makin and D. Suharwanto, "Milk production and reproduction performance of Holland Friesian dairy cattle in West Java", Jurnal Ilmu Ternak, vol. 12, no. 2, pp. 39-44, 2012. 
[24] M.E. Ensminger, "Dairy Cattle Science", third edition, The Interstate Publisher Inc., Denville,Illinois, 1993.

[25] N. Sudiana, A. Jaenudin and S. Subandi, "Influence of lactation period of quality of Holstein Friesian dairy cow milk in work area KaryaNugraha, Kuningan Regency". Kandang, vol. 4, no. 1,pp. 18-24, 2012.

[26] S. Wulandari, M. Hariadi and O.S. Widodo, "Effect of concentrate in the period of lactation to density, fat content and dry matter content of cow's milk",Agroveteriner, vol. 5, no. 2, pp. 180-188, 2017.

[27] A. Amam and P.A. Harsita, "Business development of dairy cattle: evaluation of vulnerability context and group dynamics", Jurnal Ilmiah Ilmu-Ilmu Peternakan, vol. 22, no. 1, pp. 23-34, 2019. 